\title{
Aesthetic breast augmentation with hyaluronic acid: imaging findings and implications for radiological assessment*
}

\author{
Preenchimento estético das mamas com ácido hialurônico: aspectos de imagem e implicações sobre \\ a avaliação radiológica \\ Divanei Aparecida Bottaro Criado ${ }^{1}$, Fernanda Del Campo Braojos ${ }^{2}$, Ulysses dos Santos Torres ${ }^{2}$, \\ Marcos Pontes Muniz ${ }^{3}$
}

\begin{abstract}
New injectable fillers such as hyaluronic acid have recently been employed as a non-surgical alternative to implants such as silicone for aesthetic breast enhancement. Although their utilization is not yet widespread in Brazil, radiologists should be aware of the imaging findings in this context and of the implications of the presence of this filler for the radiological evaluation in the screening for breast cancer.

Keywords: Breast; Breast implants; Hyaluronic acid; Imaging diagnosis.

Resumo Novos preenchedores injetáveis, como o ácido hialurônico, vêm sendo empregados recentemente como alternativa não cirúrgica a implantes como os de silicone para aumento estético das mamas. Embora ainda pouco difundido no Brasil, é importante que o radiologista conheça os achados de imagem nesse contexto e as implicações desse preenchedor sobre a avaliação radiológica durante o rastreamento do câncer de mama.

Unitermos: Mama; Implantes de mama; Ácido hialurônico; Diagnóstico por imagem.
\end{abstract}

Criado DAB, Braojos FDC, Torres US, Muniz MP. Aesthetic breast augmentation with hyaluronic acid: imaging findings and implications for radiological assessment. Radiol Bras. 2012 Mai/Jun;45(3):181-183.

\section{INTRODUCTION}

Aesthetic procedures for breast augmentation have become increasingly frequent in the last decades, with utilization of different techniques and materials ${ }^{(\mathbf{1})}$. Although surgical implantation of encapsulated fillers (such as silicone implants) constitute the most widely adopted technique for breast enhancement, new injectable non-encapsulated fillers have been available in the market ${ }^{(\mathbf{1})}$. Macrolane MM $^{\mathrm{TM}}$ (Q-Med AB; Uppsala, Sweden) is an injectable, biocompatible gel compound based on chemically modified hyaluronic

* Study developed at Hospital de Base - Faculdade de Medicina de São José do Rio Preto (Famerp), São José do Rio Preto, SP, Brazil.

1. Fellow Master Degree in Health Sciences, MD, Radiologist at Hospital de Base - Faculdade de Medicina de São José do Rio Preto (Famerp), São José do Rio Preto, SP, Brazil.

2. MDs, Residents of Radiology and Imaging Diagnosis at Hospital de Base - Faculdade de Medicina de São José do Rio Preto (Famerp), São José do Rio Preto, SP, Brazil.

3. PhD, Head of Department of Radiology and Imaging Diag nosis, MD, Radiologist at Hospital de Base - Faculdade de Medicina de São José do Rio Preto (Famerp), São José do Rio Preto, SP, Brazil.

Mailing Address: Dra. Divanei Aparecida Bottaro Criado. Hospital de Base - Faculdade de Medicina de São José do Rio Preto, Serviço de Radiologia e Diagnóstico por Imagem. Avenida Brigadeiro Faria Lima, 5544, Vila São Pedro. São José do Rio Preto, SP, Brazil, 15090-000. E-mail: diva_criado@hotmail.com

Received December 16, 2011. Accepted after revision February 27, 2012. acid (NASHA, nonanimal stabilized hyaluronic acid) approved in Europe in 2006 for purposes of aesthetic breast augmentation $^{(\mathbf{1})}$. In Brazil, this practice is still poorly disseminated.

The present case report is aimed at describing the radiological findings in this type of breast filling and discussing its implications on the routine radiological breast cancer screening.

\section{CASE REPORT}

A female, 53-year-old patient was submitted, on an outpatient basis, to a procedure of intramammary injection of hyaluronic acid-based gel (Macrolane) for breast augmentation for 18 months ago. During the procedure a single point on the skin of each breast was utilized for insertion of the needle. The patient was referred to the authors' institution for investigation of bilateral, painless, palpable nodules whose onset occurred after the procedure. Breast ultrasonography demonstrated the presence of multiple, predominantly anechoic, ovoid, cyst-like collections containing lowamplitude echoes, in intramuscular and intraglandular locations (Figure 1), with no evidence of nodular images. Such findings, in correlation with the patient's clinical history, were considered compatible with collections of hyaluronic acid. Correlation with mammography on craniocaudal (Figure 2) and mediolateral oblique views demonstrated a generalized increase in parenchymal radiodensity of both breasts. Breast magnetic resonance imaging (Figure 3) demonstrated the presence of hyperintense collections on T2-weighted and hypointense collections on T1-weighted images, with no enhancement following intravenous contrast agent injection, strengthening their cystic appearance. None of the imaging methods has demonstrated additional alterations, and BI-RADS ${ }^{\circledR} 2$ was the classification for both breasts.

\section{DISCUSSION}

The feasibility of an easy aesthetic procedure for breast enhancement, with local anesthesia and performed on an outpatient basis as advantages related to the use of hyaluronic acid, are considered attractive by those patients who wish to avoid a surgical procedure ${ }^{(2)}$. The aesthetic effects of this product are considered transitory for its 

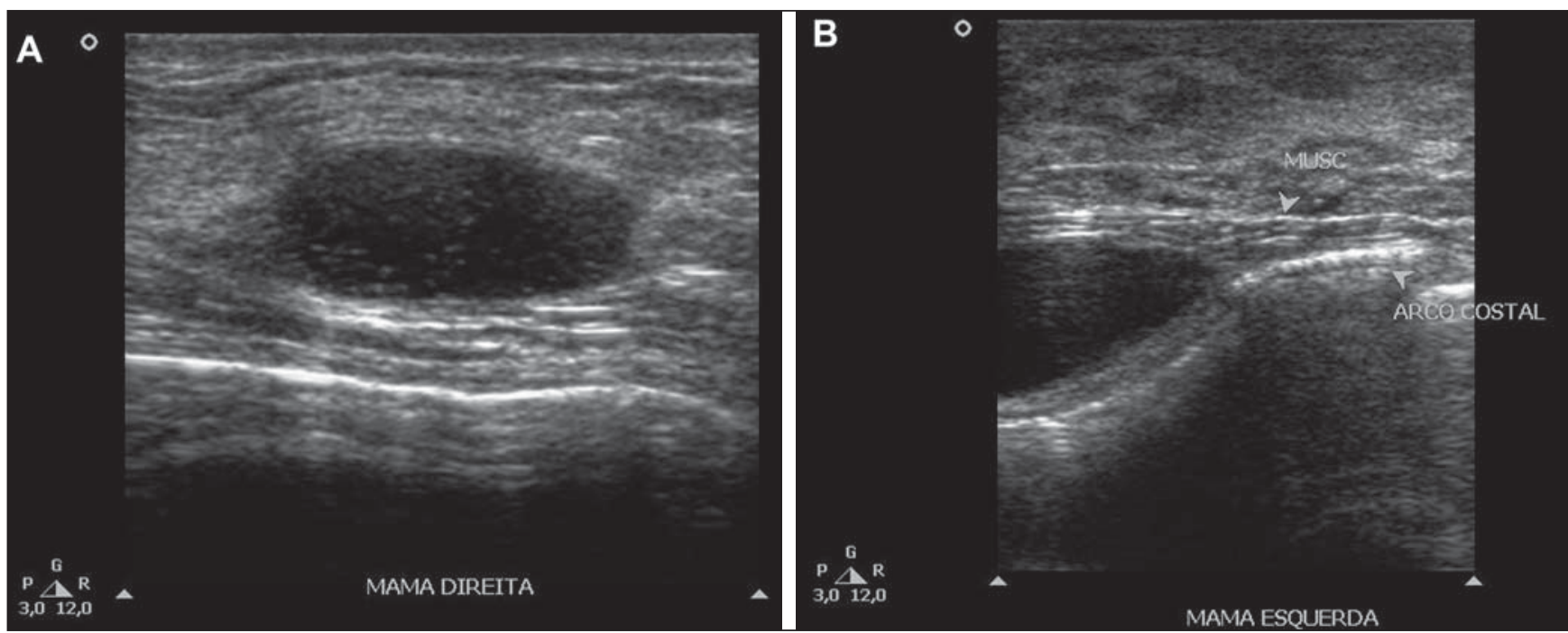

Figure 1. Breast ultrasonography demonstrating predominantly anechoic, ovoid, cystic images with low-amplitute echoes in intraglandular (A) and intramuscular (B) locations.

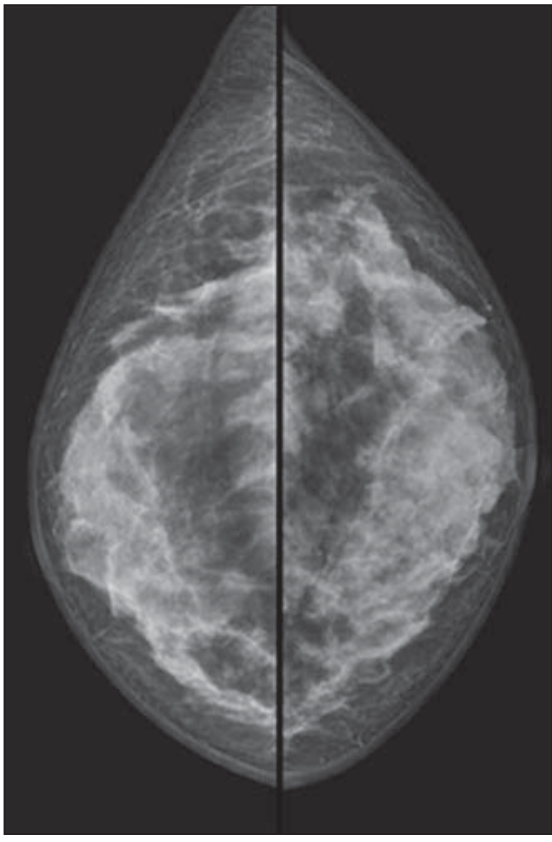

Figure 2. Mammography. Right and left craniocaudal views demonstrating bilateral diffuse increase in radiodensity of the breast parenchyma.

natural and progressive degradability, and it is expected that its reabsorption occurs over a 12- to 18 -month period ${ }^{(\mathbf{1})}$.

Although Macrolane has been approved and is currently being utilized in more than twenty countries, its utilization has not yet been approved by the Food and Drug Administration in the United States of America $^{(3)}$. Additionally, scarce scientific evidence is reported in the literature about the safety and efficacy of its use, and long-
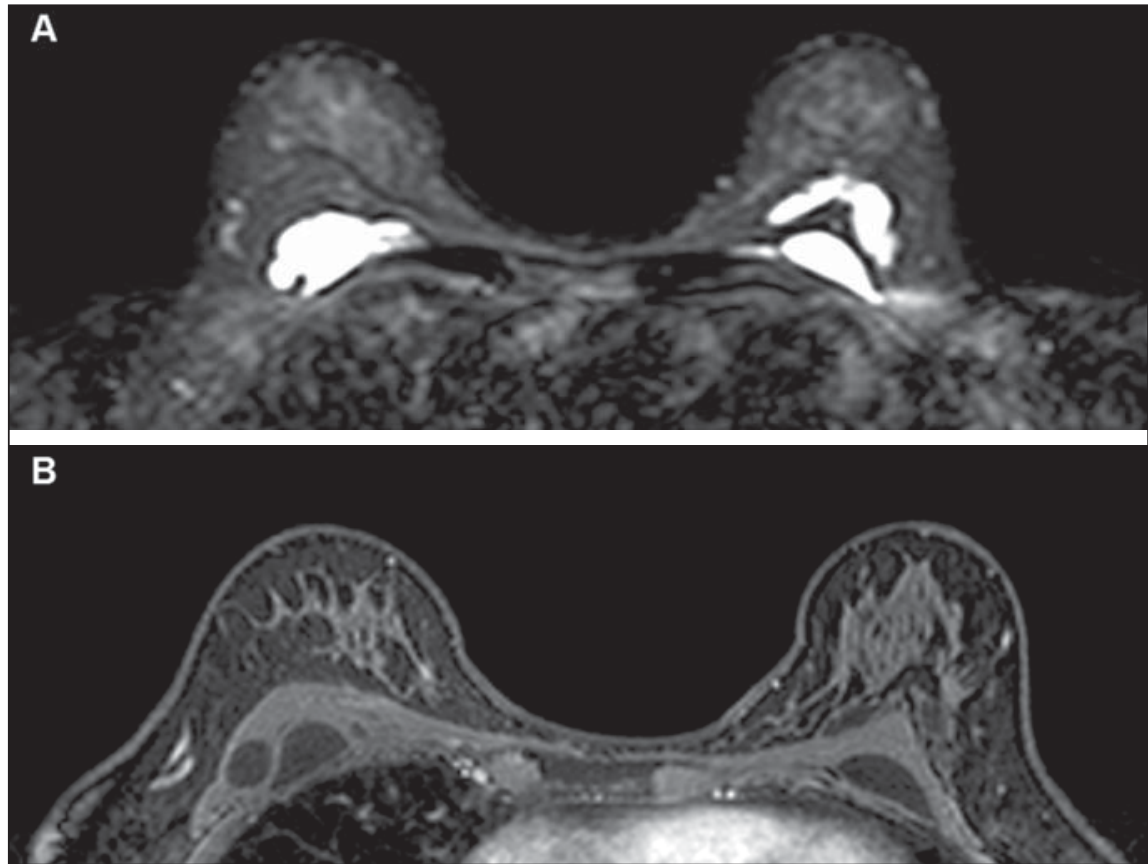

Figure 3. Breast magnetic resonance imaging. Axial sections demonstrating the presence of hyperintense collections on T2-weighted (A) and hypointense collections on T1-weighted (B) images.

term prospective studies on this matter are still to be published ${ }^{(\mathbf{1 , 3}-\mathbf{5})}$. However, some issues about the application of this product have been raised in the literature. The significant reabsorption of hyaluronic acid (about $50 \%$ over 12 months) would lead to the need for additional applications in the future to achieve the desirable aesthetic outcomes, increasing the total cost of the treatment ${ }^{(\mathbf{6})}$ and, similarly to the application in other sites, it would increase the fre- quency and risk for development of granu$\operatorname{lomas}^{(4)}$.

On the other hand, recent studies have reported only a minimum rate of hyaluronic acid degradation, with no radiological sign of reabsorption even 24 months after the procedure $^{(5)}$. While an amount between 1 and $5 \mathrm{ml}$ is injected into the face, breasts require from 100 to $150 \mathrm{ml}^{(\mathbf{1})}$, which might remain in the breast tissue for a still unknown period of time ${ }^{(5)}$. Additionally, the 
onset of adverse effects related to the product (development of nodules in $13 \%$ and mastalgia in $25 \%$ of cases after one year) ${ }^{(7)}$, which previously were considered as minimal, are currently discussed as issues of clinical significance ${ }^{(8)}$ because, in association with the decrease in the sensitivity of imaging method, young patients with recent painful breast nodules must undergo different supplementary studies and biopsies to rule out the presence of neoplasia, which represents an additional morbidity ${ }^{(8)}$. Other complications, such as superficial infections and development of abscesses, have also been described ${ }^{(\mathbf{5})}$.

From the radiological point of view, Macrolane represents a diagnostic challenge, not only for its still recent use, but also for interfering with the images interpretation $^{(5)}$. Generally, Macrolane determines an increase in the breast parenchyma radiodensity at mammography, which may be either generalized or being visualized as multiple radiodense lesions. At ultrasonography, the finding corresponds to multiple predominantly anechoic collections with internal echoes of variable sizes and echogenicities. At magnetic resonance imaging, hyaluronic acid collections appear as well delimited areas with hyperintensity on T2-weighted and hypointensity on T1- weighted images ${ }^{(\mathbf{5})}$. Although in the present case the assessment of a patient complaining of palpable nodules by means of multiple methods has demonstrated only images of well defined cyst-like collections, Macrolane collections sometimes may be involved by fibrotic capsules, assuming a more worrisome radiological appearance ${ }^{(5)}$.

According to Chaput et al. ${ }^{(3)}$, the need for repeated injections which could cause inflammation of the breast tissue and increase in the risk for cancer and development of nodules; alterations in the breast anatomy which could affect the radiological interpretation, possibly delaying the breast cancer diagnosis; and the necessity of giving priority to breast cancer screening under the public health point of view, have recently led to the prohibition of using Macrolane for aesthetic breast enhancement purposes in France ${ }^{(3)}$. Additionally, in the United Kingdom, some authors recommend that patients submitted to injections of the product undergo long-term followup, and also contraindicate its use in patients with personal/family history of breast cancer, previous history of breast cystic or pre-malignant lesions, and family history of ovarian cancer ${ }^{(2)}$.

Considering the relevant impact on the radiological interpretation of images in cases of patients submitted to breast augmentation with hyaluronic acid, it is important for the radiologist to be familiar with such imaging findings and aware of the clinical history of the patient when interpreting radiological images in these contexts.

\section{REFERENCES}

1. McCleave MJ. Is breast augmentation using hyaluronic acid safe? Aesthetic Plast Surg. 2010; 34:65-8.

2. McCleave MJ, Grover R, Jones BM. Breast enhancement using Macrolane ${ }^{\mathrm{TM}}$ : a report of complications in three patients and a review of this new product. J Plast Reconstr Aesthet Surg. 2010; 63:2108-11

3. Chaput B, Chavoin JP, Crouzet C, et al. Macrolane is no longer allowed in aesthetic breast augmentation in France. Will this decision extend to the rest of the world? J Plast Reconstr Aesthet Surg. 2012; 65:527-9.

4. Fortea-Sanchis C, Martínez-Ramos D, AlcaldeSánchez M, et al. Hyaluronic acid breast injections. Potential interferences with mammography. Cir Esp. 2010;88:421-3.

5. Pienaar WE, McWilliams S, Wilding LJ, et al. The imaging features of MACROLANE ${ }^{\mathrm{TM}}$ in breast augmentation. Clin Radiol. 2011;66:977-83.

6. Goisis M, Savoldi A, Guareschi M. Is hyaluronic acid gel a good option for breast augmentation? Aesthetic Plast Surg. 2011;35:134-6.

7. Hedén P, Olenius M, Tengvar M. Macrolane for breast enhancement: 12-month follow-up. Plast Reconstr Surg. 2011;127:850-60.

8. McGoldrick C, Khan K, Dargan D. Re: Early experience of hyaluronic acid gel for breast enhancement. J Plast Reconstr Aesthet Surg. 2011;64:1718. 